\title{
Disabling iatrogenic disorder
}

\author{
Mark Hughes, Bhathiya Wijeyekoon
}

Department of Rheumatology, East and North Hertfordshire NHS Trust, Stevenage, UK

\section{Correspondence to} Dr Bhathiya Wijeyekoon, j.wijeyekoon@nhs.net

Accepted 2 June 2016

\section{DESCRIPTION}

A 74-year-old woman presented with a 9-month history of progressive groin and shoulder pain. She was prescribed a course of prednisolone by her general practitioner, for suspected polymyalgia rheumatica (PMR), with little benefit; $\mathrm{C}$ reactive protein (CRP) was 7 prior to starting steroids. The pain had become so severe that the patient was a wheelchair user when she attended the rheuma-

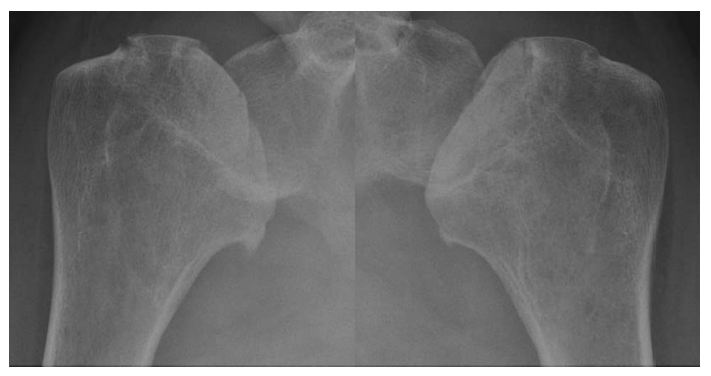

Figure 1 X-rays of both shoulders demonstrating fragmentation and collapse of the humeral heads.

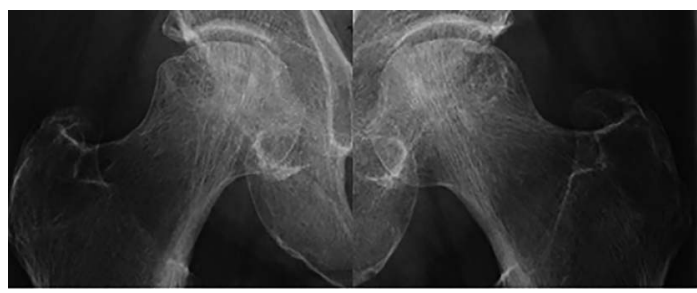

Figure 2 X-rays of both hips with subtle evidence of femoral head collapse bilaterally. tology clinic. She had a medical history of a meningioma excision, performed 18 months previously, which was followed by a prolonged course of highdose steroids; she also had a history of treated hypothyroidism.

Examination revealed a markedly restricted, and painful, range of hip and shoulder joint movement. Shoulder X-rays revealed deformities of the humeral heads (figure 1); pelvic X-ray was reported to show degenerative changes of the hips (figure 2). Blood tests demonstrated normal erythrocyte sedimentation rate, CRP, thyroid function tests and total protein; serum electrophoresis and urine Bence-Jones proteins were also negative. Neither PMR nor minor degenerative arthritis was felt to be sufficient to account for the patient's severe symptoms. The history of high-dose steroid use and humeral 'deformity' on X-ray prompted a diagnosis of avascular necrosis (AVN) to be considered.

Subsequent imaging, including MRI of the right hip (figure 3), confirmed the diagnosis of bilateral shoulder and hip AVN. In retrospect, collapse of the humeral heads is evident on X-ray (figure 1) and similar, but more subtle, changes are also evident on hip X-ray (figure 2).

Avascular necrosis of large joints is a relatively rare condition with an incidence in England of 1.4-3 cases per 100000 people. $^{1}$ Of these cases, $\sim 3 \%$ are thought to be multifocal, ${ }^{2}$ involving three or more joints. Corticosteroids are the second most common cause of AVN, after trauma, ${ }^{3}$ but account for $90 \%$ of multifocal AVN cases. ${ }^{2}$
To cite: Hughes $\mathrm{M}$, Wijeyekoon B. BMJ Case Rep Published online: [please include Day Month Year] doi:10.1136/bcr-2016214807

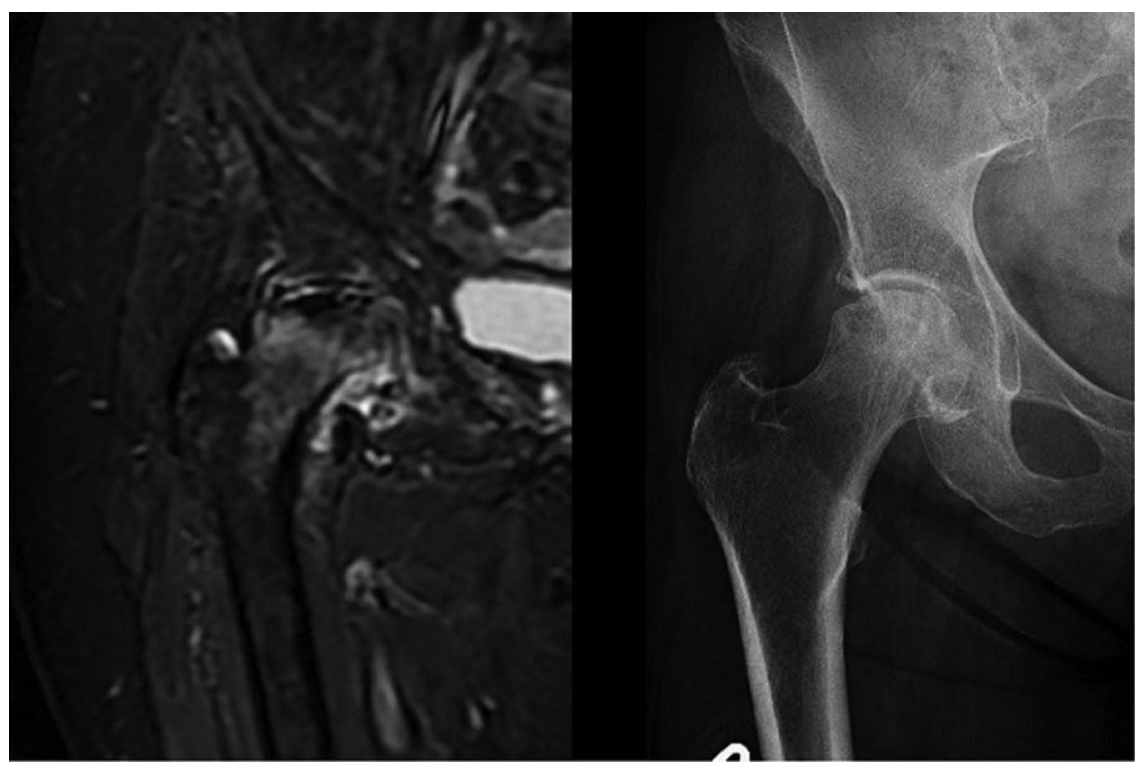

Figure 3 X-ray and short T1 inversion recovery MRI of right hip clearly demonstrating collapse of the femoral head, as well as oedema. 


\section{Learning points}

Avascular necrosis (AVN) can cause an oligoarthropathy.

- Multifocal AVN should be considered as part of the differential diagnosis in patients presenting with severe large joint pain.

- X-ray features can be subtle in early AVN, and MRI or CT scanning should be considered in suspected cases.
Contributors $\mathrm{MH}$ wrote the article, and BW reviewed and edited it.

Competing interests None declared.

Patient consent Obtained.

Provenance and peer review Not commissioned; externally peer reviewed.

\section{REFERENCES}

1 Jacobs B. Epidemiology of traumatic and nontraumatic osteonecrosis. Clin Orthop 1998;130:51-67.

2 Symptomatic multifocal osteonecrosis. A multicenter study. Collaborative Osteonecrosis Group. Clin Orthop Relat Res 1999:312-26.

3 Assouline-Dayan Y, Chang C, Greenspan A, et al. Pathogenesis and natural history of osteonecrosis. Semin Arthritis Rheum 2002;32:94-124.

Copyright 2016 BMJ Publishing Group. All rights reserved. For permission to reuse any of this content visit http://group.bmj.com/group/rights-licensing/permissions.

BMJ Case Report Fellows may re-use this article for personal use and teaching without any further permission.

Become a Fellow of BMJ Case Reports today and you can:

- Submit as many cases as you like

- Enjoy fast sympathetic peer review and rapid publication of accepted articles

- Access all the published articles

- Re-use any of the published material for personal use and teaching without further permission

For information on Institutional Fellowships contact consortiasales@bmjgroup.com

Visit casereports.bmj.com for more articles like this and to become a Fellow 